\title{
Efektywność treningu słuchowego osób z częściową głuchotą po wszczepieniu implantu ślimakowego w ocenie pacjentów i logopedów
}

\section{Effectiveness of the auditory training in patients with the partial deafness after cochlear implantation in the assessment of patients and speech therapists}

\author{
Joanna Solnica ${ }^{1,2}$, Joanna Kobosko ${ }^{1,2}$, Agnieszka Pankowska ${ }^{1,2}$, Małgorzata Zgoda ${ }^{1,2}$, \\ Henryk Skarżyński ${ }^{1,2}$
}

\author{
${ }^{1}$ Instytut Fizjologii i Patologii Słuchu, ul. Zgrupowania AK „Kampinos” 1, 01-943 Warszawa \\ ${ }^{2}$ Światowe Centrum Słuchu, ul. Mokra 17, Kajetany, 05-830 Nadarzyn
}

Adres autora: Joanna Solnica, Światowe Centrum Słuchu, ul. Mokra 17, 05-830 Nadarzyn; tel. 223560331 e-mail: j.solnica@ifps.org.pl

\begin{abstract}
Streszczenie
Wprowadzenie: Trening słuchowy obejmuje ćwiczenia z wykorzystaniem dźwięków otoczenia oraz dźwięków mowy i ma na celu wypracowanie u osób $\mathrm{z}$ wadą słuchu zasobu doświadczeń akustycznych analogicznego do tego, jaki posiadają osoby słyszące. Sukces związany $z$ leczeniem częściowej głuchoty poprzez zastosowanie implantu ślimakowego (CI) spowodował zwiększenie liczby pacjentów, którzy wymagają treningu słuchowego ukierunkowanego na rozpoznawanie dźwięków o średniej i wysokiej częstotliwości. Wobec braku pomocy dydaktycznych i rehabilitacyjnych dostosowanych do specyfiki trudności słuchowych tych pacjentów, w Klinice Rehabilitacji IFPS podjęto próbę opracowania materiałów do prowadzenia treningu słuchowego w ramach opieki pooperacyjnej.
\end{abstract}

Cel: Ocena przydatności oraz poziomu trudności treningu słuchowego z wykorzystaniem dźwięków otoczenia oraz dźwięków mowy o średniej i wysokiej częstotliwości przez pacjentów z częściową głuchotą korzystających z CI oraz logopedów.

Materiał i metody: W badaniach uczestniczyło 29 dorosłych pacjentów z częściową głuchotą korzystających z CI i objętych rehabilitacją pooperacyjną. Pacjenci oraz logopedzi niezależnie od siebie dokonywali oceny trudności i przydatności zaproponowanego treningu słuchowego wypełniając ankietę $\mathrm{z}$ wykorzystaniem pięciostopniowej skali Likerta.

Wyniki: Analiza ankiet wykazała, że zarówno pacjenci z częściową głuchotą jak i logopedzi uważają, że trening słuchowy jest trudny dla tej grupy pacjentów, zwłaszcza ćwiczenia dotyczące identyfikacji dźwięków mowy o średniej i wysokiej częstotliwości. Zaproponowane ćwiczenia w ocenie pacjentów i logopedów sprawiały znacząco większe trudności kobietom niż mężczyznom. Pomimo tego logopedzi i pacjenci potwierdzili przydatność zastosowanych zestawów ćwiczeń w procesie rehabilitacji.

Wnioski: Leczenie operacyjne pacjentów z częściową głuchotą powinno być poparte odpowiednim treningiem słuchowym ukierunkowanym na odbiór i identyfikację dźwięków o średniej i wysokiej częstotliwości. Przeprowadzone badania stanowią uzasadnienie opracowywania materiałów celem wykorzystania ich w rehabilitacji słuchu pacjentów z częściową głuchotą.

Słowa kluczowe: częściowa głuchota • implant ślimakowy • rehabilitacja • trening słuchowy

Abstract

Introduction: Auditory training consists of exercises using the environmental sounds and speech, designed to provide a hearing impaired person with the range of acoustic experiences comparable to that of a hearing person.

The successful treatment of the partial deafness with the cochlear implant (CI) resulted in the increase of the number of patients who need the auditory training directed at the recognition of mid and high frequency sounds. In the face of lack of the 
teaching aids adequate to the specific hearing problems of these patients, the Rehabilitation Clinic of the Institute of Physiology and Pathology of Hearing undertook to develop such materials for the needs of the post - CI surgery auditory training.

Aim: The assessment, by the CI users with partial deafness and by the speech therapists, of the usefulness and the difficulty level of the proposed auditory training using the environmental and speech sounds in mid and high frequencies.

Material and methods: 29 adult CI users with the partial deafness participating in the Institute's rehabilitation program. Patients and therapists, independently from one another, performed the assessment of the difficulty level and the usefulness of the proposed training by completing the questionnaire using the Likert 5-point scale.

Results: Patients with the partial deafness and speech therapists think that the proposed training is difficult for the partially deaf patients, particularly exercises in identifying mid and high frequency speech sounds. Women experienced significantly more difficulties with the proposed exercises than men. Both patients and speech therapists confirmed the usefulness of the proposed set of exercises in the rehabilitation process.

Conclusions: Surgical treatment of patients with the partial deafness should be supported by the appropriate auditory training focused on the reception and identification of mid and high frequency sounds. Our study substantiates the development of materials for rehabilitation of patients with the partial deafness.

Keywords: partial deafness $\bullet$ cochlear implant • rehabilitation • auditory training

Wykaz skrótów: CI (cochlear implant) - implant ślimakowy; PDT (partial deafness treatment) - leczenie częściowej głuchoty; EC (electric complement) - stymulacja elektryczna jako uzupełnienie do słuchu istniejącego na niskich częstotliwościach; EAS (electric-acoustic stimulation) - elektryczno-akustyczna stymulacja; ES (electric stimulation) - tylko stymulacja elektryczna

\section{Wstęp}

W literaturze przedmiotu dokonuje się podziału na „wychowanie słuchowe” (auditory learning) oraz „trening słuchowy" (auditory training). Pierwszy termin odnosi się do dzieci, u których uszkodzenie słuchu nastąpiło przed opanowaniem mowy i zawierają się w nim różnego rodzaju oddziaływania, wykorzystujące zachowane resztki słuchu, podejmowane w celu kształtowania i rozwijania języka. Natomiast termin „trening słuchowy”, określany czasem także, jako „kształcenie słuchu” używany jest w stosunku do osób, u których uszkodzenie słuchu nastąpiło po opanowaniu podstaw systemu językowego. Ćwiczenia słuchowe prowadzone w ramach treningu słuchowego opierają się na umiejętnościach językowych pacjenta, a także wcześniejszych doświadczeniach słuchowych [Löwe 1995].

„Wychowanie słuchowe”, jak i „trening słuchowy” odnoszą się ściśle do procesu rehabilitacji osób po operacji wszczepienia implantu ślimakowego (CI). Dostarczenie pacjentom odpowiednich urządzeń wspomagających słyszenie (aparaty słuchowe lub/i implanty ślimakowe) dostosowanych do charakterystyki uszkodzenia słuchu i umożliwiających odbiór dźwięków jest zaledwie początkiem drogi do świata dźwięków. Każdy pacjent, niezależnie od wieku i zdobytych doświadczeń, zarówno językowych, jak i słuchowych, potrzebuje pomocy specjalistów w zakresie nauki słuchania. Końcowy efekt leczenia operacyjnego z zastosowaniem CI jest uzależniony od wielu czynników, należy jednak podkreślić, że ważne miejsce wśród nich zajmuje proces planowej i systematycznej rehabilitacji [Skarżyński, Szuchnik, Mueller-Malesińska 2004].

Polski program rehabilitacji słuchowej pacjentów po operacji wszczepienia CI został opracowany w latach 1992 1997 na bazie światowych oraz własnych doświadczeń zdobytych w tym zakresie [Skarżyński, Szuchnik, Mueller-Malesińska 2004]. Jednak nieustanny rozwój naukowy w dziedzinie otolaryngologii i postęp technologiczny, zmiany kryteriów kwalifikowania pacjentów do operacji wszczepiania CI, a co za tym idzie pojawianie się coraz młodszych, a także zupełnie nowych grup pacjentów, wymaga od specjalistów stałego dopracowywania metod wykorzystywanych w procesie rehabilitacji, tak aby uczynić go efektywnym i dostosowanym do różnych potrzeb.

Liczne działania podejmowane na rzecz osób z uszkodzonym słuchem spowodowały, że została wyłoniona zupełnie nowa grupa pacjentów, u których zachowane jest słyszenie w zakresie niskich częstotliwości, przy jednoczesnym braku możliwości słyszenia tonów wysokich [Skarżyński, Lorens, Piotrowska, Anderson 2007]. Są to osoby, u których klasyczne aparaty słuchowe nie przynosiły oczekiwanych efektów, a kształt audiogramu nie spełniał kryterium do zastosowania CI. Taki rodzaj ubytku słuchu określany jest zgodnie z propozycją H. Skarżyńskiego [Skarżyński, Lorens, Piotrowska 2003] mianem częściowej głuchoty i obecnie jest leczony z dużym sukcesem za pomocą wszczepiania implantu ślimakowego. Pierwsza operacja wszczepienia CI u osoby dorosłej z częściową głuchotą została przeprowadzona w 2002 roku przez prof. Skarżyńskiego, a satysfakcjonujące wyniki zaowocowały pierwszym wszczepieniem CI u dziecka z tego typu niedosłuchem w 2004 roku [Skarżyński, Lorens, Piotrowska, Anderson 2007].

Specyficzne trudności w zakresie odbioru i identyfikacji dźwięków w tej grupie pacjentów oraz możliwości słuchowe, jakie uzyskują dzięki zastosowaniu CI wpływają na konieczność opracowania nowych narzędzi do organizacji efektywnej rehabilitacji słuchu.

\section{Cel}

Celem przeprowadzonych badań była ocena przydatności oraz poziomu trudności zaproponowanego treningu 


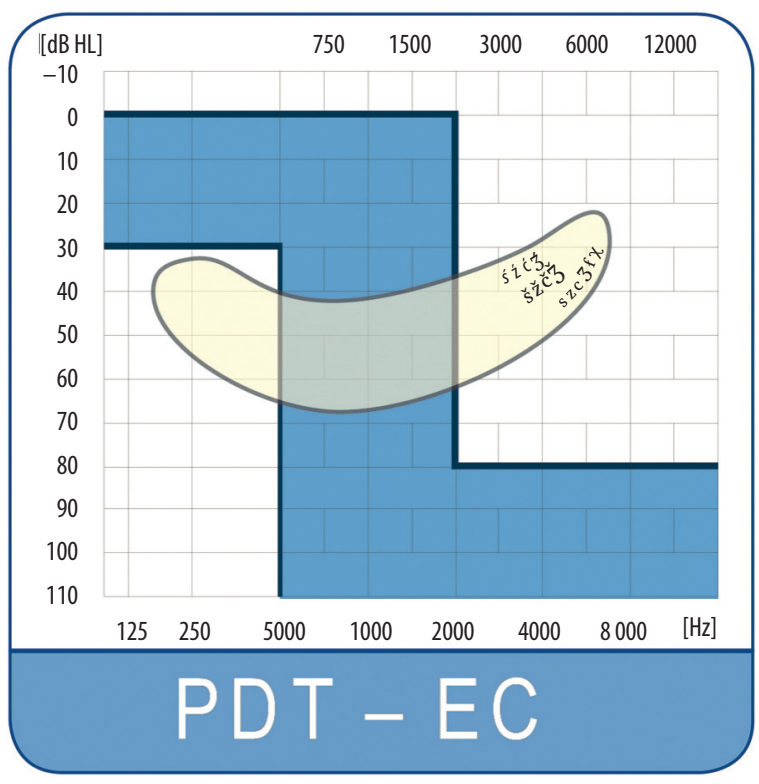

Rycina 1. Audiogram pacjentów z częściową głuchotą z grupy PDT-EC (electric complement)

słuchowego z wykorzystaniem dźwięków otoczenia oraz dźwięków mowy o średniej i wysokiej częstotliwości przez pacjentów z częściową głuchotą korzystających z CI, a także przez logopedów prowadzących rehabilitację.

\section{Materiał i metody}

Wszyscy pacjenci korzystali ze stymulacji elektryczno-akustycznej (PDT - EAS), z wykorzystaniem procesora typu Duet lub Hybrid oraz wzmocnienia akustycznego niskich częstotliwości w tym samym uchu [Skarżyński, Lorens, Piotrowska, Skarżyński 2010]. W badanej grupie były 22 kobiety $(75,9 \%)$ oraz 7 mężczyzn $(24,1 \%)$ w wieku od 19 do $80(M=46,59 ; S D=15,9)$ lat. Ze względu na wiek badani pacjenci zostali podzieleni na dwie grupy: „młodszych” do 37 lat, w której znalazło się 9 osób (31\%) oraz „starszych” od 40 lat wzwyż, którzy stanowili 20 osób (69\%). Diagnozę głuchoty w przypadku 3 pacjentów (10,3\%) postawiono przed 3 r.ż. (prelingwalna), u 8 osób $(27,6 \%)$ między 3 a 7 r.ż. (perilingwalna), a u pozostałych 18 osób $(62,1 \%)$ po 7 r.ż. (postlingwalna) [Skarżyński, Mueller-Malesińska, Wojnarowska 1997]. Ze względu na rozkład liczebności pacjentów o różnym typie częściowej głuchoty w dalszych analizach statystycznych z uwzględnieniem tego kryterium wzięto pod uwagę wyniki jedynie pacjentów z głuchotą peri- i postlingwalną.

Pacjenci uczestniczyli w terapii słuchowej prowadzonej w Klinice Rehabilitacji IFPS w systemie wizyt - raz w miesiącu przez okres minimum 6 miesięcy od momentu podłączenia procesora mowy. Trening słuchowy był prowadzony w oparciu o opracowane materiały wykorzystujące dźwięki otoczenia oraz dźwięki mowy o średniej i wysokiej częstotliwości. Przygotowane zestawy ćwiczeń obejmowały: wykrywanie, dyskryminację oraz identyfikację dźwięków o średniej i wysokiej częstotliwości. Ćwiczenia te obejmowały dwa rodzaje dźwięków: dźwięki otoczenia (dźwięki przedmiotowe) oraz dźwięki mowy prezentowane odpowiednio w zestawach zamkniętych, półotwartych

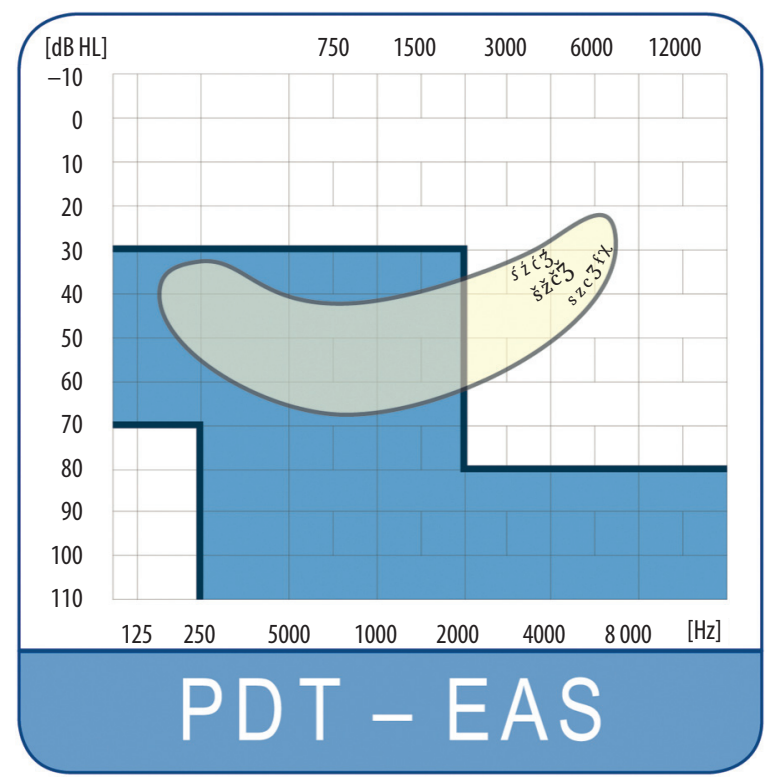

Rycina 2. Audiogram pacjentów z częściową głuchotą z grupy PDT-EAS (electric-acoustic stimulation)

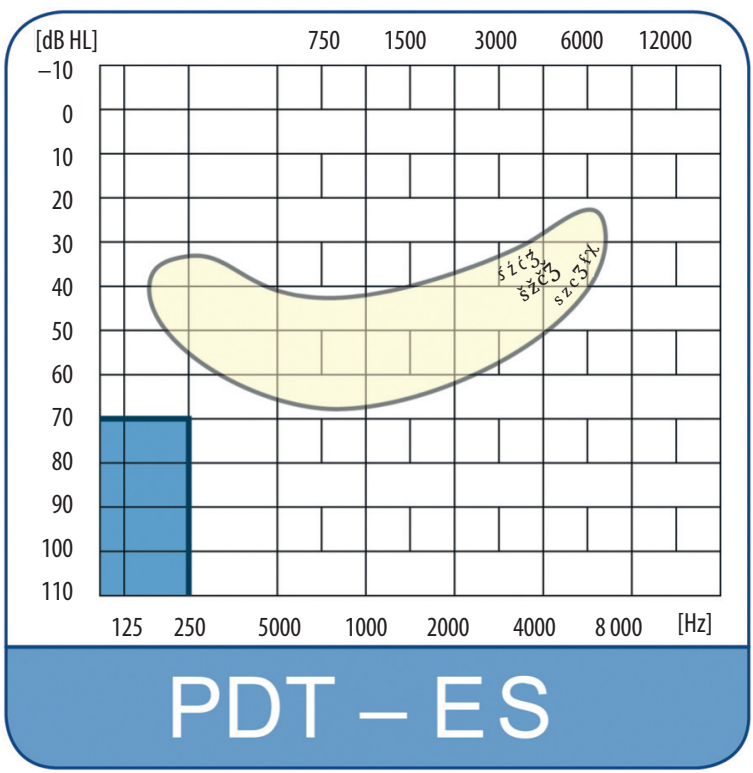

Rycina 3. Audiogram pacjentów z częściową głuchotą z grupy PDT-ES (electric stimulation)

i otwartych. Na początku programu rehabilitacji do ćwiczeń wykorzystywano dźwięki przedmiotowe (np. rozpoznawanie dźwięków występujących w otoczeniu cechujących się wysoką częstotliwością, takich jak: ćwierkanie ptaka, dzwonek telefonu, cymbałki, gwizdek, szum wody, szelest torebki foliowej) i stopniowo w miarę wzrostu umiejętności słuchowych pacjenta włączano ćwiczenia z wykorzystaniem dźwięków mowy o średniej i wysokiej częstotliwości (np. rozpoznawanie spółgłosek w sylabach: asa, aša, aca; dyskryminacja wyrazów różniących się jedną spółgłoską: kasa - kasza).

Na audiogramach Ryciny 1-3 obrazujących charakterystykę słyszenia właściwą dla pacjentów z częściową głuchotą 

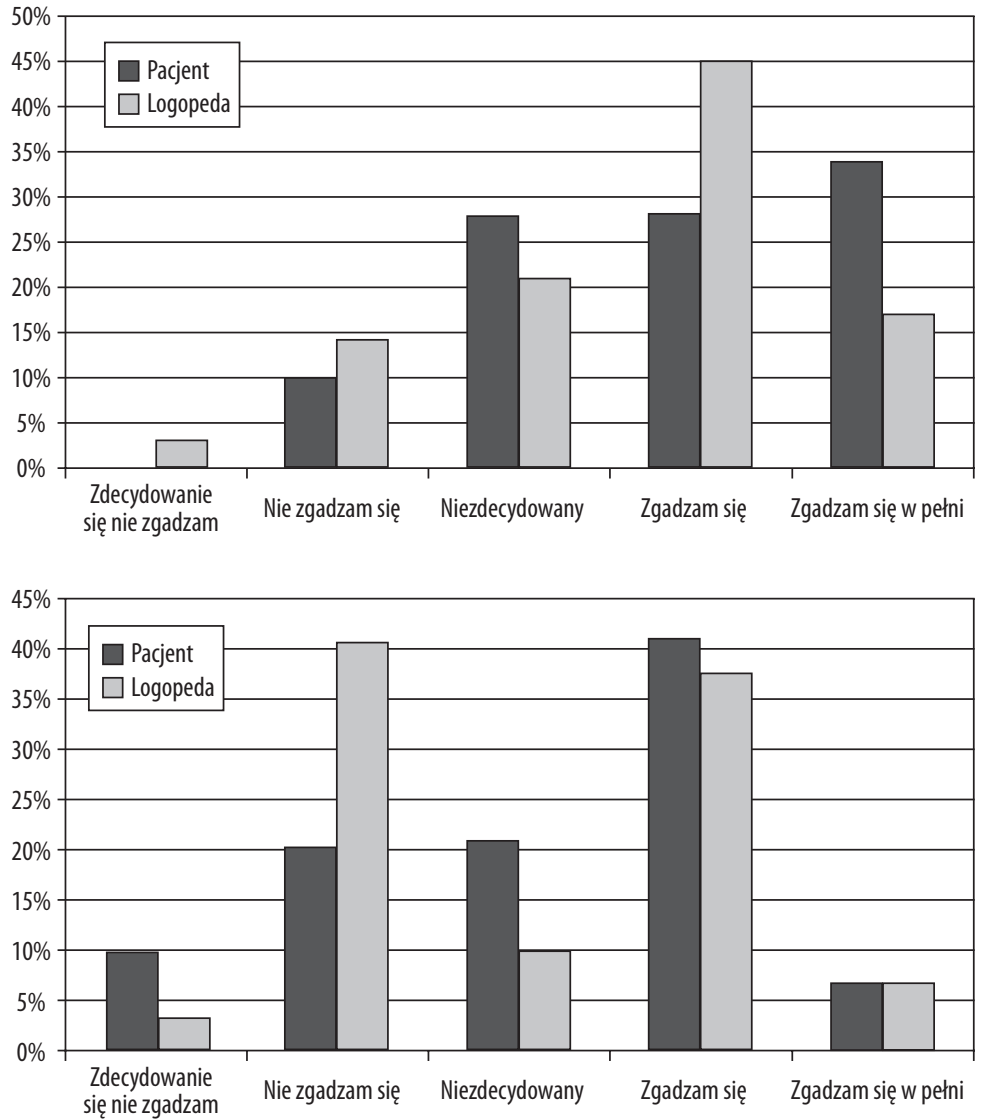

Rycina 4. Rozkład procentowy odpowiedzi pacjentów i logopedów dotyczący ogólnej trudności treningu słuchowego

Rycina 5. Rozkład procentowy odpowiedzi pacjentów i logopedów dotyczący trudności ćwiczeń obejmujących identyfikację dźwięków otoczenia o średniej i wysokiej częstotliwości zakwalifikowanych do trzech grup - zgodnie z klasyfikacją Skarżyńskiego [Skarżyński, Lorens, Piotrowska, Skarżyński 2010] umieszczono „banana mowy” z wyszczególnionymi spółgłoskami języka polskiego, których pacjenci nie słyszeli przed operacją. Ćwiczenia obejmowały dyskryminację i identyfikację wskazanych dźwięków mowy w sylabach, wyrazach i zdaniach.

Celem oceny stopnia trudności i przydatności zaproponowanego treningu słuchowego użyto ankiety składającej się z 4 stwierdzeń np. Zaproponowany trening słuchowy zawierający dźwięki otoczenia i dźwięki mowy o średniej i wysokiej częstotliwości sprawia mi / pacjentowi trudność, w której do oceny wykorzystano pięciostopniową skalę Likerta. Odpowiedzi: zdecydowanie sie nie zgadzam, nie zgadzam się, niezdecydowany, zgadzam się, zgadzam się w petni punktowane były według skali od 1 do 5 . Ankiety wypełniali pacjenci oraz logopedzi po zakończeniu pierwszych zajęć, podczas których prezentowano ćwiczenia o różnym stopniu trudności z wykorzystaniem zarówno dźwięków otoczenia, jak i dźwięków mowy. Logopedami prowadzącymi trening słuchowy oraz wypełniającymi ankietę były wyłącznie kobiety.

W analizie statystycznej wyników do porównań średnich ocen pacjentów i logopedów wykorzystano nieparametryczny test Wilcoxona, zaś test U Manna-Whitneya do porównań średnich ocen pacjentów i logopedów z uwzględnieniem ich płci, wieku i typu głuchoty pacjenta. Do pomiaru siły związku między ocenami pacjentów i logopedów wykorzystano współczynnik korelacji rho Spearmana.

\section{Wyniki}

Wyniki dotyczące ogólnej oceny przez pacjentów i logopedów stopnia trudności treningu słuchowego z uwzględnieniem płci, wieku, typu głuchoty - prelinwalna, perilingwalna, postlingwalna pacjentów (odpowiedź na pytanie nr 1 Ankiety - Zaproponowany trening słuchowy zawierający dźwięki otoczenia i dźwięki mowy o średniej i wysokiej częstotliwości sprawia mi / pacjentowi trudność) przedstawiono na Rycinie 4

Zaprezentowane wyniki wskazują, że ponad połowa pacjentów (tj. 62\%), jak również $62 \%$ logopedów biorących udział w badaniu zgadza się lub zgadza się w pełni z tym stwierdzeniem. Niezdecydowanych w tej kwestii jest 28\% pacjentów, jak również $21 \%$ logopedów. Analiza statystyczna przeprowadzona testem nieparametrycznym Wilcoxona wykazała, że pacjenci i logopedzi podobnie spostrzegają stopień trudności treningu słuchowego - nie ma między nimi istotnie statystycznych różnic. Stopień trudności treningu słuchowego w ocenie pacjentów nie różnił się istotnie ze względu na płeć, wiek oraz typ głuchoty. Logopedzi dokonywali podobnej oceny pacjentów bez względu na ich płeć, wiek i typ głuchoty.

Wyniki dotyczące oceny stopnia trudności ćwiczeń z wykorzystaniem dźwięków otoczenia przez pacjentów i logopedów $\mathrm{z}$ uwzględnieniem płci, wieku, typu głuchoty - prelinwalna, perilingwalna, postlingwalna pacjentów (odpowiedź na pytanie nr 2 Ankiety - Odczuwam / pacjent odczuwa trudność w identyfikacji dźwięków otoczenia o wysokiej częstotliwości) przedstawiono na Rycinie 5. 

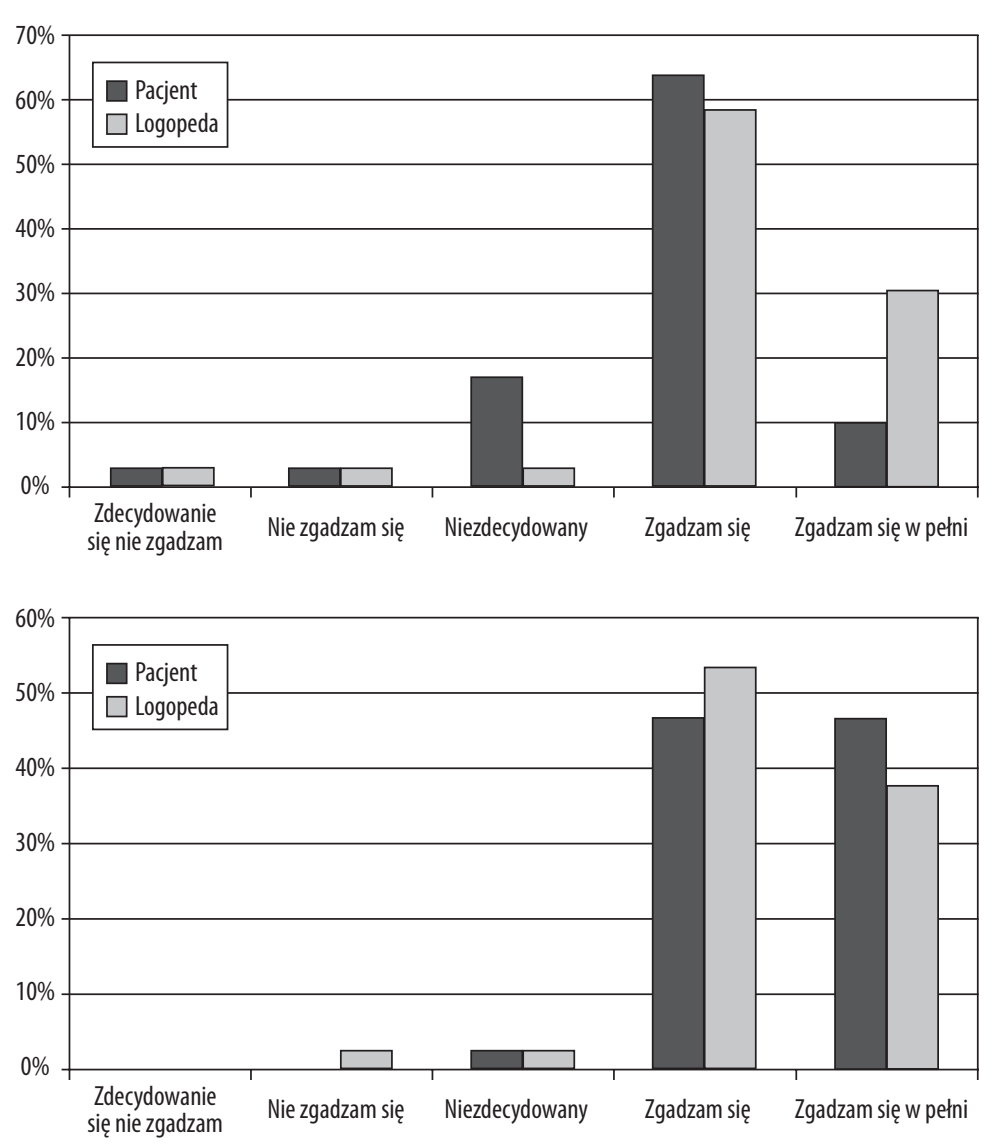

Rycina 6. Rozkład procentowy odpowiedzi pacjentów i logopedów dotyczący trudności ćwiczeń obejmujących identyfikację dźwięków mowy o średniej i wysokiej częstotliwości

Rycina 7. Rozkład procentowy odpowiedzi pacjentów i logopedów dotyczący przydatności zaproponowanego treningu słuchowego
Przedstawiony rozkład procentowy odpowiedzi wskazuje, że $48 \%$ pacjentów oraz $45 \%$ logopedów zgadza się lub zgadza się w petni z tym stwierdzeniem. Jednak dość liczna grupa, bo aż $21 \%$ pacjentów i $41 \%$ logopedów również z nim nie zgadza się. Stopień trudności ćwiczeń z wykorzystaniem dźwięków otoczenia nie różni się istotnie statystycznie (test Wilcoxona) w zależności od tego, czy ankietę wypełniał pacjent czy logopeda. Natomiast spostrzeganie stopnia trudności w zależności od płci pacjenta okazało się znacząco odmienne - kobiety, w porównaniu z mężczyznami, oceniają tego typu ćwiczenia jako trudniejsze (test U Manna-Whitneya $-\mathrm{U}=38,5 ; \mathrm{p}=0,04)$. Logopedzi różnią się w sposób istotny w ocenie stopnia trudności ćwiczeń obejmujących identyfikację dźwięków otoczenia, w zależności od tego jaka jest płeć pacjenta (test U Manna-Whitneya - U=39; $\mathrm{p}=0,04$ ) logopedzi (kobiety) oceniają pacjentów płci żeńskiej, jako posiadających większe trudności w tym obszarze, w porównaniu do pacjentów płci męskiej. Kryterium wieku i typu głuchoty nie różnicowało istotnie oceny stopnia trudności tego ćwiczenia zarówno przez pacjentów, jak i logopedów.

Wyniki dotyczące ceny stopnia trudności ćwiczeń z wykorzystaniem dźwięków mowy przez pacjentów i logopedów z uwzględnieniem płci, wieku, typu głuchoty - prelinwalna, perilingwalna, postlingwalna pacjentów (odpowiedź na pytanie nr 3 Ankiety - Odczuwam / pacjent odczuwa trudność $w$ rozpoznawaniu wyrazów zawierających głoski o wysokiej częstotliwości: ś, ź, ć, dź, s, $z, c, d z, s z, r z, c z, d \dot{z}$ przedstawiono na Rycinie 6.

Odpowiedzi przedstawione na Rycinie 6 wskazują, że zdecydowana większość pacjentów, (tj. 76\%), jak również 90\% logopedów, zgadza się i zgadza się w petni ze stwierdzeniem, że identyfikacja dźwięków mowy o średniej i wysokiej częstotliwości jest dla pacjentów trudna. Pacjenci oceniali tę kategorię ćwiczeń jako istotnie łatwiejszą niż logopedzi (test Wilcoxona $-\mathrm{Z}=-2,11 ; \mathrm{p}=0,03$ ) bez względu na płeć, wiek i typ głuchoty. W ocenie logopedów kobiety miały istotnie większe trudności niż mężczyźni podczas wykonywania tego typu ćwiczeń (test U Manna-Whitneya - $U=35 ; p=0,01$ ). Ponadto osoby $z$ głuchotą perilingwalną zostały przez nich ocenione jako posiadające znacząco większe trudności w omawianym zakresie niż osoby postlinwalnie ogłuchłe (test $U$ Manna-Whitneya - $U=42$; $\mathrm{p}=0,05)$. Wiek pacjentów nie miał istotnego znaczenia w tym, jak logopedzi spostrzegali doświadczaną przez nich trudność w rozpoznawaniu wyrazów zawierających głoski o wysokiej częstotliwości: ś, ź, ć, ̧́, s, z, c, Z, š, ž, cz, ž.

Wyniki dotyczące oceny przydatności treningu słuchowego przez pacjentów i logopedów z uwzględnieniem płci, wieku, typu głuchoty - prelinwalna, perilingwalna, postlingwalna pacjentów (odpowiedź na pytanie $\mathrm{nr} 4$ ankiety - Osoby z czéściowa głuchota po operacji wszczepienia implantu ślimakowego potrzebuja rehabilitacji stuchu - odpowiednich ćwiczeń słuchowych $z$ wykorzystaniem zarówno dźwięków otoczenia, jak i dźwięków mowy o wysokiej częstotliwości) przedstawiono na Rycinie 7.

Grupa 96\% pacjentów oraz 93\% logopedów, zgadza się lub zgadza się w petni z tym stwierdzeniem (Rycinie 7). W ocenie przydatności treningu słuchowego dla osób z częściową głuchotą pacjenci i logopedzi nie różnią się w sposób istotny statystycznie (test Wilcoxona), a pacjenci także ze względu 
na płeć, wiek i typ głuchoty. Jako osoby bardziej potrzebujące treningu słuchowego logopedzi (kobiety) wskazują istotnie częściej pacjentów płci żeńskiej (test U Manna-Whitneya - U=36; $\mathrm{p}=0,02$ ). Okazało się, że logopedzi uważają trening słuchowy za istotnie bardziej przydatny osobom $\mathrm{z}$ głuchotą perilingwalną $\mathrm{w}$ porównaniu $\mathrm{z}$ osobami ogłuchłymi postlingwalnie (test U Manna-Whitneya - U=40; $\mathrm{p}=0,04)$. Wiek pacjentów nie różnicował istotnie logopedów odnośnie oceny przydatności treningu słuchowego.

W odniesieniu do oceny efektywności treningu słuchowego w ocenie pacjentów i logopedów postawiono pytanie, czy istnieje związek pomiędzy oceną efektywności treningu słuchowego (ankieta) dokonywaną przez pacjentów i logopedów. Stwierdzono, że im większa trudność pacjenta w ocenie logopedy w zakresie identyfikacji dźwięków otoczenia o wysokiej częstotliwości (pyt. nr 2 ankiety), tym większa jest trudność $\mathrm{w}$ tym zakresie w ocenie samego pacjenta - stwierdzono umiarkowaną dodatnią korelację między wynikami w ocenach pacjentów i logopedów (rho Spearmana $-\mathrm{rho}=0,5 ; \mathrm{p}<0,01)$.

Nie stwierdzono istotnej zależności pomiędzy ocenami dokonywanymi przez pacjentów i logopedów odnośnie: ogólnej trudności tego treningu słuchowego (pyt. nr 1 ankiety), jego elementów obejmujących identyfikację dźwięków otoczenia o średniej i wysokiej częstotliwości (pyt. nr 3 ankiety), jak również jego przydatności w procesie rehabilitacji po operacji wszczepienia implantu ślimakowego (pyt. nr 4 ankiety). Oceny te nie współwystępują ze sobą.

\section{Dyskusja}

Przeprowadzone badania wstępne stanowiły próbę oceny zaproponowanego treningu słuchowego dla pacjentów z częściową głuchotą po operacji wszczepienia implantu ślimakowego (CI) z perspektywy pacjentów i logopedów. Stanowią okazję do zebrania opinii dotyczących rehabilitacji postrzeganej jako trening słuchowy ukierunkowany na trudności słuchowe pacjenta, a w tym przypadku na odbiór i identyfikację dźwięków o wysokiej częstotliwości odbieranych za pomocą CI oraz ich integrację z dźwiękami odbieranymi z wykorzystaniem słuchu naturalnego.

Ewaluacja efektywności treningu słuchowego dokonana przez pacjentów i logopedów była w większości przyjętych kryteriów zbliżona. Trudność w odniesieniu do identyfikacji dźwięków mowy o wysokiej częstotliwości wydaje się być mniejsza w opinii pacjentów niż logopedów. Rozbieżność ta może być spowodowana występowaniem u pacjentów tendencji do niedoceniania swoich trudności w identyfikacji dźwięków mowy, co znajduje odzwierciedlenie w rozumieniu mowy na drodze słuchowej. Ocena wybranych umiejętności odbywała się na pierwszych zajęciach rehabilitacyjnych poświęconych treningowi słuchowemu, po miesiącu korzystania z CI. Samo zastosowanie CI daje możliwość odbioru „nowych” dźwięków o wysokiej częstotliwości, których pacjent nie słyszał przed operacją, jednak jest to zbyt krótki czas, aby w pełni wykorzystać jego możliwości. Implant ślimakowy stwarza pacjentom możliwość odbioru dźwięków, lecz doskonalenie umiejętności słuchowych z wykorzystaniem tego urządzenia powinno być poparte odpowiednim treningiem słuchowym [Fu, Galvin 2008].
Stwierdzona u logopedów i pacjentów rozbieżność w ocenie stopnia trudności ćwiczeń identyfikacji dźwięków mowy o wysokiej częstotliwości (logopedzi uznali je za trudniejsze niż sami pacjenci) może też wynikać z odmiennych kryteriów, jakimi kierują się logopedzi i pacjenci. Kryteria te uwzględniają specjalistyczną wiedzę logopedyczną oraz doświadczenia kliniczne związane z procesem nabywania umiejętności słuchowych po operacji wszczepienia CI. Z tego też względu inne były oczekiwania logopedów w zakresie identyfikacji dźwięków mowy, w efekcie być może bardziej adekwatne do realnych możliwości słuchowych pacjenta. Podobnie można wyjaśnić fakt, iż logopedzi uznali trening słuchowy za bardziej przydatny pacjentom z głuchotą perilingwalną niż postlingwalną, choć sami pacjenci nie różnili się w dokonywaniu tej oceny ze względu na posiadany typ głuchoty.

Przyczyna różnic między pacjentami i logopedami w udzielanych odpowiedziach odnośnie stopnia trudności identyfikacji dźwięków mowy o wysokiej częstotliwości może leżeć w sformułowaniu pytania na ten temat. Treść tego pytania mogła okazać się zbyt ogólna dla pacjentów, którzy nie są specjalistami w dziedzinie surdologopedii, fonetyki akustycznej czy lingwistyki. U pacjentów mogły pojawić się trudności $\mathrm{w}$ interpretacji omawianego pytania, a także w odniesieniu go do własnych doświadczeń.

Otrzymane wyniki badań wskazują na istotną rolę płci w ocenie efektywności treningu słuchowego przez pacjentów (kobiety i mężczyzn) oraz logopedów, którymi były wyłącznie kobiety. Pacjenci płci żeńskiej przypisują sobie większe trudności wyłącznie w zakresie identyfikacji dźwięków otoczenia o wysokiej częstotliwości, jak np. świergot ptaka, gwizdek czajnika, dzwonek telefonu. Logopedzi z kolei spostrzegają pacjentki jako osoby mające większą trudność w zakresie identyfikacji dźwięków otoczenia i dźwięków mowy o wysokiej częstotliwości oraz wskazują je jako osoby bardziej potrzebujące treningu słuchowego. Być może uzyskane rezultaty wiążą się z większymi umiejętnościami adaptacyjnymi mężczyzn do korzystania $\mathrm{z}$ nowego urządzenia, jakim jest CI, a także z wykorzystywaniem efektywniejszych sposobów radzenia sobie w sytuacjach trudnych, co wykazały badania prowadzone $\mathrm{z}$ udziałem dorosłych pacjentów postlingwalnie ogłuchłych korzystających z CI [Kobosko, Pankowska, Skarżyński 2012]. W naszej opinii, korzyści uzyskiwane z użytkowania CI zależą od bardzo wielu czynników, a płeć może być jednym $\mathrm{z}$ nich.

W ocenie pacjentów i logopedów dotyczącej efektywności treningu słuchowego przeznaczonego dla osób z częściową głuchotą po operacji wszczepienia CI nie miał znaczenia wiek pacjenta. Okazało się, że w odniesieniu do większości zastosowanych kryteriów oceny (ankieta) nie ma związku między tym, jak oceniają efektywność treningu słuchowego pacjenci, a jak spostrzegają ją logopedzi.

Podsumowując, można stwierdzić, że uzyskane opinie, zwłaszcza ze strony pacjentów z częściową głuchotą korzystających z CI, wskazują na znaczenie treningu słuchowego ukierunkowanego na dźwięki o wysokiej częstotliwości, a także na potrzebę uczestnictwa pacjenta w tej formie rehabilitacji. Osoby z częściową głuchotą, z zachowanym słuchem w zakresie niskich częstotliwości, komunikujące 
się werbalnie i często aktywne zawodowo są postrzegane przez najbliższe środowisko jako osoby niewymagające rehabilitacji. Niekiedy dopiero spotkania z logopedą i wykonywanie odpowiednich ćwiczeń słuchowych uświadamiają pacjentom potrzebę rehabilitacji i możliwości postępu w zakresie percepcji słuchowej, co w rezultacie sprzyja efektywniejszemu komunikowaniu się w sytuacjach społecznych. Właściwy sposób organizowania rehabilitacji może także poprawiać funkcjonowanie słuchowe pacjentów korzystających z CI, którzy posiadają wysoki poziom umiejętności słuchowych, a takimi niewątpliwie są pacjenci z częściową głuchotą [Fu, Galvin 2008].

Zaproponowane narzędzie oceny efektywności treningu słuchowego wymaga weryfikacji i dalszego opracowania, jednakże stanowi cenne źródło wstępnych informacji na temat spostrzegania treningu słuchowego z perspektywy zarówno pacjentów z częściową głuchotą korzystających z CI, jak i logopedów.

\section{Wnioski}

1. U pacjentów z częściową głuchotą, korzystających z implantu ślimakowego, identyfikacja dźwięków o średniej i wysokiej częstotliwości, a co za tym idzie lepsze rozumienie mowy, powinno być poparte odpowiednim treningiem słuchowym, na co wskazują zbieżne oceny jego stopnia trudności w opinii logopedów i pacjentów.
2. Efektywność treningu słuchowego w ocenie pacjentów z częściową głuchotą, korzystających z CI, jak i logopedów jest odmienna - pacjenci spostrzegają go jako łatwiejszy niż logopedzi.

3. W ocenie efektywności treningu słuchowego dokonywanej przez pacjentów istotną rolę odgrywa płeć pacjenta kobiety spostrzegają trening słuchowy jako trudniejszy. 4. Płeć pacjenta i typ głuchoty (peri- lub postlingwalna) odgrywa istotną rolę w ocenie efektywności treningu słuchowego pacjentów dokonywanej przez logopedów (kobiety) - logopedzi spostrzegają trening słuchowy jako trudniejszy dla kobiet, zwłaszcza kobiet z głuchotą perilingwalną.

5. Brak jest zależności między tym, jak logopedzi, a jak pacjenci z częściową głuchotą, korzystający z CI, spostrzegają efektywność treningu słuchowego w zakresie jego ogólnego stopnia trudności i trudności w rozpoznawaniu wyrazów zawierających głoski o wysokiej częstotliwości, a także w zakresie przydatności treningu słuchowego dla pacjentów.

6. Opieka pooperacyjna pacjentów z częściową głuchotą, powinna obejmować oddziaływania także innych specjalistów, np. psychologów.

7. Wyniki przeprowadzonych badań pilotażowych zawierają wskazówki które mogą być wykorzystane przy dalszym opracowaniu materiałów dydaktycznych do rehabilitacji pacjentów z częściową głuchotą po operacji wszczepienia implantu ślimakowego, a także w ocenie czynionych przez nich postępów.

\section{Piśmiennictwo:}

1. Fu Q.J., Galvin J.J. III: Maximizing cochlear implant patients' performance with advanced speech training procedures. Aug Hear Res, 2008; xx(242): 198-208

2. Kobosko J., Pankowska A., Skarżyński H.: Strategie radzenia sobie ze stresem u osób postlingwalnie ogłuchłych korzystających z implantu ślimakowego w porównaniu z populacją ogólną słyszących. Otolaryngologia Polska, 2012; 2: 132-37

3. Löwe A.: Historia wychowania słuchowego. (W:) Wychowanie słuchowe. Historia - metody - możliwości. Wydawnictwo Naukowe PWN, Warszawa, 1995; 44

4. Skarżyński H., Szuchnik J., Mueller-Malesińska M.: Polski program implantów ślimakowych. (w) Implanty ślimakowe rehabilitacja. Stowarzyszenie Przyjaciół Osób Niesłyszących i Niedosłyszących „Człowiek - Człowiekowi”, Warszawa, 2004; $46-49$
5. Skarżyński H., Lorens A., Piotrowska A., Anderson I.: Preservation of low frequency hearing in partial deafness cochlear implantation (PDCI) using the round window surgical approach. Acta Otolaryngol, 2007a;127: 41-48

6. Skarżyński H., Lorens A., Piotrowska A.: A new method of partial deafness treatment. Med Sci Monit, 2003; 9(4): CS20-24

7. Skarżyński H., Lorens A., Piotrowska A., Anderson I.: Partial deafness cochlear implantation in children. Int J Pediatr Otorhinolaryngol, 2007; 71(9): 1407-13

8. Skarżyński H., Lorens A, Piotrowska A., Skarżyński P.: Hearing preservation in partial deafness treatment, Med Sci Monit, 2010; 16(11): CR555-62

9. Skarżyński H., Mueller-Malesińska M., Wojnarowska W.: Klasyfikacja zaburzeń słuchu. Audiofonologia, 1997; 10: 49-51 